\title{
Comparative cytochemical study of dipeptidyl aminopeptidase (DAP) II and IV in normal and malignant haemic cells
}

\author{
MR KHALAF, PC BEVAN, FGJ HAYHOE \\ From the Department of Haematological Medicine, University Clinical School, Cambridge
}

SUMMARY Modified cytochemical methods were used to show dipeptidyl aminopeptidases (DAP) II and IV in peripheral blood buffy coat preparations and bone marrow smears. In 23 normal buffy coats both enzymes were confined to lymphocytes. DAP II was found in T and B lymphocytes (about $80 \%$ ) while DAP IV was restricted to T lymphocytes only (around 46\%). In 11 normal bone marrows DAP II was found in $53 \%$ of the lymphocytes, as well as in plasma cells, macrophages, and occasional myeloblasts. DAP IV was found only in lymphocytes (around $32 \%$ ).

DAP II activity, but not DAP IV activity, was present in all of the mast cells in a case of systemic mastocytosis. Whereas DAP II was found, to a variable extent, in leukaemic myeloblasts, monoblasts, proerythroblasts, and in megakaryoblasts in 52 cases of acute myeloid leukaemia, DAP IV was not shown. Variable positivity to DAP II and DAP IV was found in the lymphoblasts in seven cases of acute lymphoblastic leukaemia, in 14 cases of B chronic lymphocytic leukaemia, and in three cases of non-Hodgkin's lymphoma. DAP II activity was variable compared with DAP IV activity, which was constantly reduced. Virtually all of the myeloma cells $(96 \%)$ in five cases of multiple myeloma and two cases of plasma cell leukaemia were DAP II positive and DAP IV negative. In 10 cases of hairy cell leukaemia most hairy cells were positive to DAP II (74\%) with no demonstrable DAP IV activity. In a single case of Sézary's syndrome around $90 \%$ of the helper $T$ cells were positive to DAP II with no DAP IV activity.

Showing that dipeptidyl aminopeptidase IV (DAP IV, EC 3.4.14.4) is a reliable enzyme cytochemical marker of $T$ lymphocytes has received much more attention $^{1-10}$ than showing the reliability of dipeptidyl aminopeptidase II (DAP II, EC 3.4.14.2) in haemic cells. ${ }^{210}$ Lojda $^{2}$ first described the DAP II enzyme in blood lymphocytes in man.

This study describes the optimal conditions for showing cytochemically the presence of DAP II and IV in peripheral blood and bone marrow cells and the distribution of these enzymes in both normal and malignant haemic cells.

\section{Material and methods}

Heparinised peripheral blood buffy coats, bone marrow smears, and sheep erythrocyte rosetting lymphocyte preparations ${ }^{11}$ were used. This investigation entailed 34 normal (controls) and 97 pathological

Accepted for publication 18 March 1986 samples (Tables 1 and 2). The cytochemical demonstration of DAP II and DAP IV was performed according to the method of Lojda et al, ${ }^{12}$ with slight modifications. The effect of fixation, substrate concentration, two coupling agents, two buffers, and conditions of incubation on the rate and intensity of the enzymatic reaction were studied. Controls included smears incubated without substrates or diazonium salts.

The following methods were found to give the best results for showing the presence of both enzymes:

\section{REAGENTS}

Fixative Formaldehyde vapour (formaldehyde solution $37-40 \%$ (w/v), BDH “Analar").

Substrates Lysyl-alanyl-4-methoxy-2-naphthylamide (LAMN) for DAP II, glycyl-prolyl-4-methoxy-2naphthylamide (GPMN) for DAP IV (Bachem).

Solvent Dimethylformamide (DMF) from BDH "Analar."

Buffers $0.1 \mathrm{~mol} / 1$ cacodylate buffer $\mathrm{pH} 5 \cdot 2 ; 0 \cdot 1 \mathrm{M}$ phosphate buffer $\mathrm{pH} \mathbf{7 \cdot 2}$. 
Table 1 DAP II and IV activities in normal and myeloproliferative disorders

\begin{tabular}{|c|c|c|c|c|c|c|c|}
\hline \multirow[t]{3}{*}{ Clinical category } & \multirow[t]{3}{*}{ Sample } & \multirow{3}{*}{$\begin{array}{l}\text { No of } \\
\text { cases }\end{array}$} & \multirow[t]{3}{*}{ Cell type } & \multicolumn{4}{|c|}{ No of positive cells (\%) } \\
\hline & & & & \multicolumn{2}{|l|}{$D A P I I$} & \multicolumn{2}{|l|}{$D A P I V$} \\
\hline & & & & $\operatorname{Mean}(S D)$ & Range & $\operatorname{Mean}(S D)$ & Range \\
\hline Normal & $\begin{array}{l}\text { Buffy coat } \\
\text { Bone marrow }\end{array}$ & $\begin{array}{l}23 \\
11\end{array}$ & $\begin{array}{l}\text { Lymphocyte } \\
\text { Lymphocyte }\end{array}$ & $\begin{array}{l}80(9) \\
53(21)\end{array}$ & $\begin{array}{l}57-96 \\
28-92\end{array}$ & $\begin{array}{l}46(16) \\
32(21)\end{array}$ & $\begin{array}{l}22-89 \\
14-84\end{array}$ \\
\hline $\begin{array}{l}\text { Systemic mastocytosis } \\
\text { Acute myeloid leukaemia: }\end{array}$ & Buffy coat & 1 & Mast cell & 98 & & 0 & \\
\hline Acute myeloblastic leukaemia & Buffy coat & 26 & Blast & $51(39)$ & $0-98$ & 0 & \\
\hline Acute promyelocytic leukaemia & Buffy coat & 2 & Promyelocyte & 0 & & 0 & \\
\hline Acute myelomonocytic leukaemia & Buffy coat & 15 & Blast & $58(38)$ & $0-100$ & 0 & \\
\hline Acute monocytic leukaemia & $\begin{array}{l}\text { Buffy coat } \\
\text { Bone marrow }\end{array}$ & $\begin{array}{l}5 \\
1\end{array}$ & Blast & $\begin{array}{l}76(41) \\
93\end{array}$ & 3-98 & 0 & \\
\hline Erythroleukaemia & Buffy coat & 1 & Blast & 70 & & & \\
\hline Acute megakaryoblastic leukaemia & Buffy coat & 2 & Blast & $80(7)$ & $75-85$ & 3 & \\
\hline
\end{tabular}

Coupling agent Fast blue B salt (FBB) from Sigma. Counterstain Carazzi's haematoxylin, as prepared elsewhere. ${ }^{13}$

Mounting medium Apathy's mounting medium (Raymond A Lamb).

INCUBATION MIXTURE FOR DAP II

Dissolve $4 \mathrm{mg}$ of LAMN in $0.25 \mathrm{ml}$ of DMF. Add to $4.75 \mathrm{ml}$ of cacodylate buffer and mix well. Add $5 \mathrm{mg}$ of FBB and mix well. Adjust $\mathrm{pH}$ to $5 \cdot 2$, if necessary, by $0 \cdot 2 \mathrm{M}$ hydrochloric acid and filter.

INCUBATION MIXTURE FOR DAP IV

Dissolve $3 \mathrm{mg}$ of GPMN in $0.2 \mathrm{ml}$ DMF. Add to $4.6 \mathrm{ml}$ of phosphate buffer and mix well. Dissolve $5 \mathrm{mg}$ of FBB in $0.2 \mathrm{ml} \mathrm{DMF}$. Add to the above solution and mix well. Adjust $\mathrm{pH}$ to $7 \cdot 2$ by $0.2 \mathrm{M}$ hydrochloric acid if necessary and filter.

\section{TECHNIQUE}

1 Fix air dried smears for two minutes in formaldehyde vapour at room temperature.

2 In a humid chamber apply the incubation mixture to smears using a $200 \mu \mathrm{l}$ pipette $(200 \mu \mathrm{l} / \mathrm{smear})$ and cover each smear with a $22 \times 64 \mathrm{~mm}$ coverslip, spreading the mixture over the smear.

3 Incubate for two hours at $37^{\circ} \mathrm{C}$ (DAP II) and for 45 minutes at room temperature (DAP IV).

4 Remove the coverslips carefully and wash in distilled water.

5 Counterstain in Carazzi's haematoxylin for five to 10 minutes.

6 Wash briefly in alkaline tap water.

7 Mount the smears using Apathy's mounting medium.

\section{COMMENTS}

1 The substrates are expensive, so the use of a humid chamber is recommended.

2 Because of their reported stability, ${ }^{14}$ it is feasible to study the DAP II and IV activities in smears up to several months old.

3 Mounting in Apathy's medium was used to preserve the azo dye reaction product as it dissolves in immersion oil.

Table 2 DAP II and IV activities in lymphoproliferative disorders

\begin{tabular}{|c|c|c|c|c|c|c|c|}
\hline \multirow[t]{3}{*}{ Clinical category } & \multirow[t]{3}{*}{ Sample } & \multirow{3}{*}{$\begin{array}{l}\text { No of } \\
\text { cases }\end{array}$} & \multirow[t]{3}{*}{ Cell type } & \multicolumn{4}{|c|}{ No of positive cells (\%) } \\
\hline & & & & \multicolumn{2}{|l|}{$D A P I I$} & \multicolumn{2}{|l|}{$D A P I V$} \\
\hline & & & & $\operatorname{Mean}(S D)$ & Range & $\operatorname{Mean}(S D)$ & Range \\
\hline $\begin{array}{l}\text { Acute lymphoblastic leukaemia } \\
\text { B prolymphocytic leukaemia } \\
\text { Chronic lymphocytic leukaemia } \\
\text { Hairy cell leukaemia } \\
\text { Sézary syndrome } \\
\text { Non-Hodgkin's lymphoma* } \\
\text { Multiple myeloma } \\
\text { Plasma cell leukaemia }\end{array}$ & $\begin{array}{l}\text { Buffy coat } \\
\text { Buffy coat } \\
\text { Buffy coat } \\
\text { Buffy coat } \\
\text { Buffy coat } \\
\text { Buffy coat } \\
\text { Buffy coat } \\
\text { Bone marrow } \\
\text { Buffy coat }\end{array}$ & $\begin{array}{r}7 \\
1 \\
15 \\
10 \\
1 \\
3 \\
5 \\
2\end{array}$ & $\begin{array}{l}\text { Lymphoblast } \\
\text { Lymphocyte } \\
\text { Lymphocyte } \\
\text { Lymphocyte } \\
\text { Hairy cell } \\
\text { Sézary cell } \\
\text { Lymphocyte } \\
\text { Plasma cell } \\
\text { Plasma cell }\end{array}$ & $\begin{array}{l}31(38) \\
51(40) \\
0 \\
63(24) \\
74(19) \\
89 \\
84(11) \\
96(2) \\
96\end{array}$ & $\begin{array}{r}0-96 \\
5-95 \\
21-93 \\
43-98 \\
73-94 \\
94-98 \\
95,97\end{array}$ & $\begin{array}{l}2(3) \\
29(5) \\
0 \\
7(10) \\
0 \\
0 \\
13(2) \\
0 \\
0\end{array}$ & $\begin{array}{c}0-6 \\
26-35 \\
0-42\end{array}$ \\
\hline
\end{tabular}

*Includes a case in leukaemic phase. 


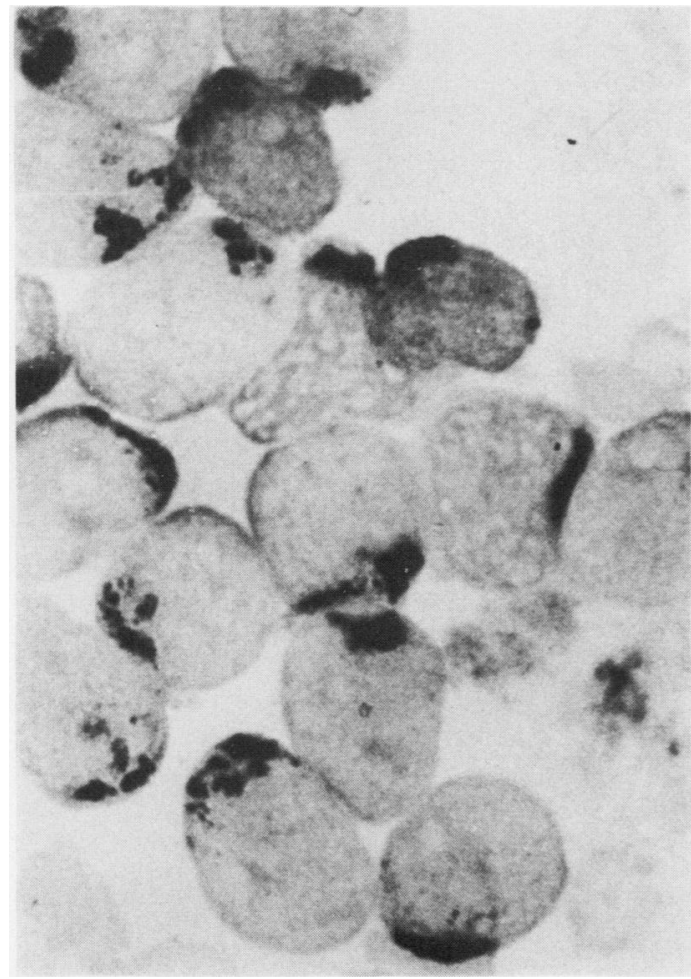

Fig 1 DAP II. Acute myeloid leukaemia: all myeloblasts in this case show strong focal pattern of reaction.

\section{Results}

Both enzymes liberate 4-methoxy-2-naphthylamine, which couples promptly with the diazonium salt FBB in the incubation mixture to form a deep red insoluble azo dye. The reaction product appeared within the cell cytoplasm either as a scattered granular or localised granular pattern, as described by Lojda. ${ }^{2}$ Diffuse staining sometimes occurred.

In smears 100 potentially reacting cells of the types described in relation to the various conditions studied were found, and the number of these reacting positively was recorded.

\section{ACTIVITY OF DAP II AND IV IN NORMAL}

\section{HAEMIC CELLS}

Cells of buffy coat smears Only lymphocytes displayed DAP II and IV activities (Table 1). The reaction product of both enzymes was intense, either as scattered granules or localised as one, two, or more granules in the cytoplasm. Occasionally, it tended to be diffuse.

Cells of bone marrow smears Only lymphocytes, plasma cells, and macrophages exhibited DAP II

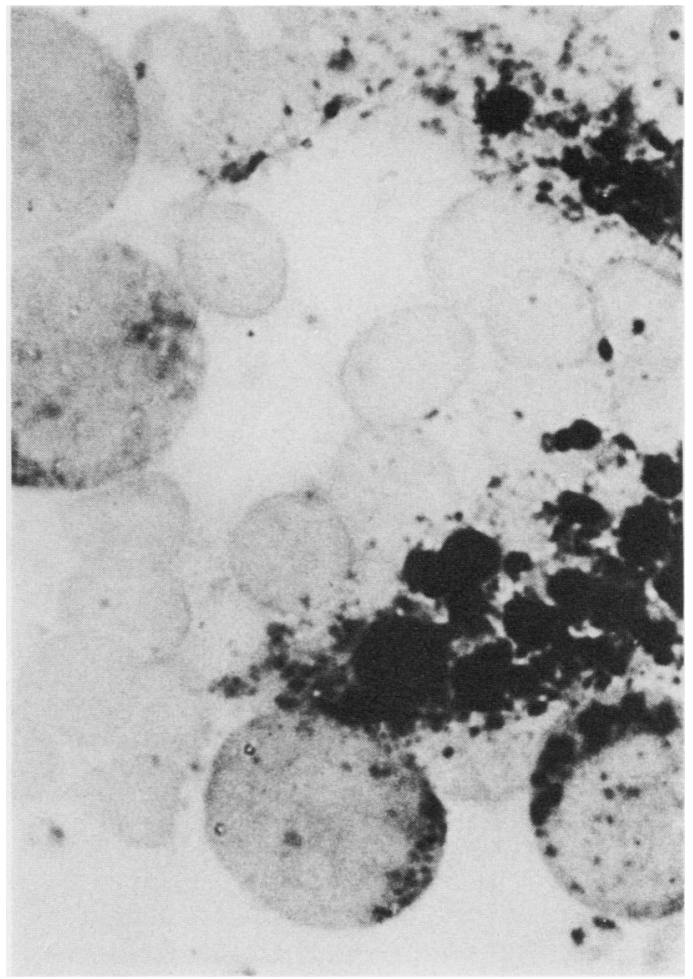

Fig 2 DAP II. Acute myelomonocytic leukaemia: four monoblasts exhibit strong scattered granular positivity and one is negative; macrophage shows coarse blocks of reaction product.

activity. Normal myeloblasts occasionally showed focal positivity. Plasma cell activity varied from strong granular or chunk like positivity to weak granular or diffuse positivity. The macrophages occasionally showed granular positivity in the central area of the smear. Fragments exhibited diffuse staining, presumably due to the macrophage component. Of normal bone marrow cells, only lymphocytes exhibited DAP IV activity (Table 1).

Sheep erythrocyte rosetting preparation In the case of rosetting lymphocytes $92 \%$ exhibited DAP II activity compared with $65 \%$, which exhibited DAP IV activity. Lymphocytes without rosettes were completely negative for DAP IV, while $8 \%$ were positive for DAP II. The predominant pattern of DAP II and IV activities in the positive rosetting lymphocytes was localised coarse granular, although some cells exhibited scattered granular reactions.

ACTIVITY OF DAP II AND IV IN VARIOUS

HAEMATOLOGICAL DISORDERS

Tables 1 and 2 show the type of reacting cells and the 


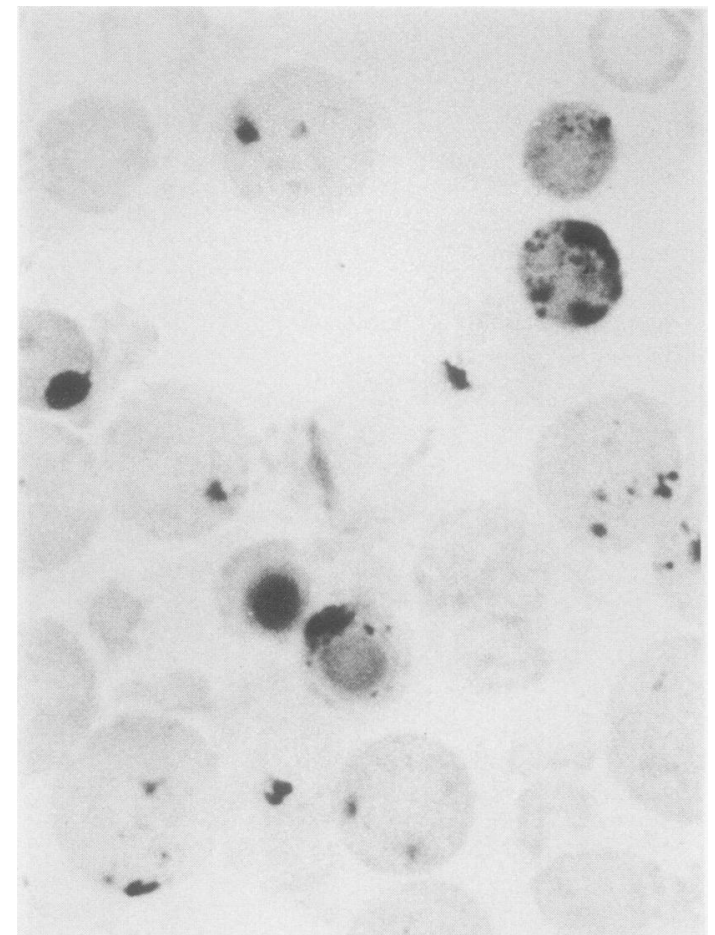

Fig 3 DAP II. Common acute lymphoblastic leukaemia: most lymphoblasts show focal positivity or scattered granular reaction while lymphocytes present show reactions varying from single coarse block to scattered granular positivity. One normoblast displays coarse granular reaction and another is negative.

percentage of positivity in smears from various haematological disorders.

Acute myeloid leukamia Activity of DAP II in leukaemic myeloblasts, monoblasts, proerythroblasts, megakaryoblasts varied (Table 1). The reaction pattern was either focal, scattered granular, or diffuse (Figs. 1 and 2). Four of the 26 myeloblastic leukaemia cases studied showed completely negative myeloblasts.

In a case of mixed acute myeloid leukaemia - that is, erythroid, myeloid, monocytic, megakaryocytic with eosinophilic, and basophilic components (? chronic myeloid leukaemia transformation)-all cell lineages exhibited the enzyme activity.

For DAP IV the leukaemic blasts showed no activity except in a single case of acute megakaryoblastic leukaemia, confirmed by platelet peroxidase ultracytochemistry and monoclonal antibody studies, where $3 \%$ of megakaryoblasts showed DAP IV scattered granular positivity.

Systemic mastocytosis In a single case all mast cells

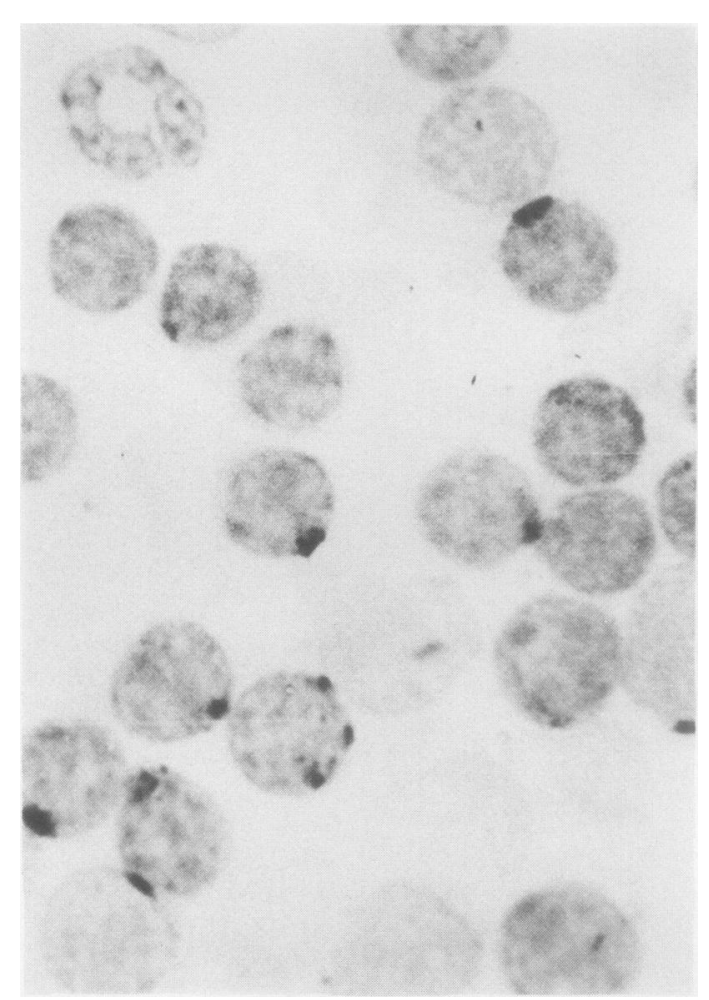

Fig 4 DAP II. Common lymphoblastic leukaemia: single dot reaction pattern of positivity predominates in most lymphocytes.

showed scattered granular positivity for DAP II but were negative for DAP IV.

Acute lymphoblastic leukaemia $(A L L)$ Of the seven cases of ALL studied, five were identified as common $:$ ALL using monoclonal antibodies. The phenotype of the two other cases was not identified. DAP II activity in lymphoblasts varied considerably from complete negativity in one case (phenotype was not identified) to weak (less than $5 \%$, two common ALL cases) or strong (55-96\%, three cases of common ALL) positivity. The pattern of staining was either a localised (Fig. 3) or scattered granular positivity, but the local- of ised pattern was more prominent. For DAP IV a $\tilde{\circ}$ small percentage of lymphoblasts $(6 \%)$ was positive in three cases of common ALL while the remaining four cases of ALL were completely negative.

$B$ prolymphocytic leukaemia $(B-P L L)$ In one case the prolymphocytes were completely negative for $\stackrel{\circ}{?}$ both DAP II and IV.

Chronic lymphocytic leukaemia (CLL) The mean of positive lymphocytes was lower than that of the normal mixed $T$ and $B$ lymphocyte population of peripheral blood (Tables 1 and 2), but the degree of 
positivity varied widely between individual cases (Fig. 4). With DAP IV the number of positive lymphocytes was almost always considerably reduced (Table 2). In one case of B-CLL, however, DAP IV positive lymphocytes were within the normal range among the buffy coat and bone marrow cells.

Further to this, we found few DAP IV positive lymphocytes $(7 \%)$ in a case of suppressor T-CLL, while $40 \%$ of lymphocytes showed DAP II activity.

Hairy cell leukaemia (HCL) In 10 cases of hairy cell leukaemia the DAP II reaction pattern varied from focal to scattered granular positivity in hairy cells, although DAP IV activity was absent.

During an emerging remission of hairy cell leukaemia treated with human lymphoblastoid interferon (IFN-d), the number of lymphocytes increased considerably. Thus the buffy coat smears showed a large number of DAP IV positive lymphocytes. Activity of the individual lymphocytes, however, did not increase.

Sézary Syndrome (SS) In a single case of Sézary syndrome the Sézary cells showed scattered granular patterns of DAP II positivity while they were completely devoid of DAP IV activity. After six months of treatment with cyclophosphamide, adriamycin, vincristine, and prednisolone about $24 \%$ of DAP IV positive cells emerged while the proportion of DAP II positive cells did not change.

Non-Hodgkin's lymphoma (NHL) Of the three cases studied, the lymphoid cells did not exhibit a change from the normal values, or a characteristic pattern of DAP II reaction (Tables 1 and 2). In the case of severe invasion of bone marrow and peripheral blood by non-Hodgkin's lymphoma the proportion of positive lymphoid cells was unchanged. As to DAP IV, however, lymphoid cells showed a considerable reduction in the number of positive lymphocytes (Table 2).

Multiple myeloma (MM) In the five cases studied most myeloma cells showed DAP II reactions, although they were completely devoid of DAP IV.

Plasma cell leukaemia (PCL) In the two cases most plasma cells exhibited scattered granular or focal cytoplasmic reaction patterns for DAP II while they were negative for DAP IV (Table 2).

\section{Discussion}

In this study various modifications of previously published methods for showing the presence of DAP II and $I^{12}$ in peripheral blood and bone marrow cells were investigated. The optimal conditions for showing both enzymes at the cellular level were determined. The results showed a higher percentage of DAP II positively reacting normal lymphocytes of peripheral blood (about $80 \%$ ) compared with pre- vious reports of $50 \%{ }^{10}$ or $60 \% .^{2}$ This was most probably due to incubation at $37^{\circ} \mathrm{C}$ and the extension of the incubation time to two hours. The mean of DAP IV positive lymphocytes of peripheral blood was about $46 \%$ compared with $39 \%$ reported by Lojda et al. ${ }^{12}$

The results obtained with cytochemical tests on erythrocyte rosetting lymphocytes indicated that DAP II is present in T lymphocytes and also in some B lymphocytes, which supports previous findings. ${ }^{2} 10$ DAP IV activity seems to be confined to T lymphocytes; not all of them, however, exhibited the activity. This finding agrees with other studies on $T$ and $B$ lymphocyte subpopulations identified by rosetting techniques. $^{45} 7$

Fewer bone marrow lymphocytes exhibited DAP II and IV activity compared with peripheral blood lymphocytes, which probably reflects the higher percentage of $B$ cells in the bone marrow ${ }^{15}$ compared with those in the peripheral blood.

In seven cases of ALL a wide variation in DAP II activity was found, with all lymphoblasts in one case being totally negative. For DAP IV four cases of common ALL did not exhibit any activity in the lymphoblasts, while the remaining three cases exhibited DAP IV positivity in a few lymphoblasts.

In B-CLL DAP II activity was variable, ranging from $21 \%$ to $93 \%$ but no diagnostic pattern was discernible. This contrasts with the findings for DAP IV: the present study and previous reports ${ }^{210}$ have shown that in B-CLL the number of positive lymphocytes is greatly reduced. The low percentage of positively reacting lymphocytes in these cases most probably represents residual T lymphocytes. Furthermore, we found considerably reduced activity of DAP IV in a case of suppressor T-CLL, a feature previously described by Crockard et $a l^{9}$ and reduced activity of DAP II as well, while Invernizzi et al ${ }^{10}$ reported normal or appreciably increased DAP IV activity in two cases of helper T-CLL. This difference may be of value in discriminating between helper and suppressor $\mathrm{T}$ cell disorders.

DAP II positivity was found in hairy cells of hairy cell leukaemia and in plasma cells of both multiple myeloma and plasma cell leukaemia. This differs from the findings of Invernizzi et al, ${ }^{10}$ who reported that hairy cells were negative and that myeloma cells were only occasionally positive. This discrepancy is probably accounted for by the relatively long fixation time used by the authors. We found that a fixation time in excess of two minutes in formaldehyde vapour is inhibitory to DAP II. They also used fast garnet GBC as a coupling agent instead of the more suitable FBB, which has been shown to be the best in a comparative study using various diazonium salts, including fast garnet GBC. ${ }^{16}$ 
The lack of DAP IV activity in hairy cells and malignant plasma cells further supports the findings that lymphoid cells in B lymphoproliferative disorders do not show DAP IV activity. ${ }^{481718}$

In this study a case of Sézary syndrome with an excess of circulating $T$ helper cells showed DAP II activity without any DAP IV positivity. The finding of DAP IV positivity is in keeping with previous studies of four cases of Sézary syndrome. ${ }^{79}$ Whether this negativity of $T$ lymphocytes in Sézary syndrome represents a difference in the level of differentiation is uncertain.

Interestingly, after six months of treatment a moderate number of DAP IV positive cells emerged in our patient with Sézary syndrome. This, perhaps, may have been due to an increase of non-Sézary cells of T lymphocyte origin, so DAP IV cytochemistry could possibly be used in the follow up and checking of response to treatment of these patients.

This study indicates that DAP II is present in normal lymphocytes, plasma cells, and macrophages. The enzyme is also found in most malignant haemic cells of most leukaemias, lymphomas, and multiple myelomas; thus it does not seem to be of much help in discriminating between various disorders.

DAP IV is absent in B cell derived neoplasia-that is B-prolymphocytic leukaemia, B-chronic lymphocytic leukaemia, hairy cell leukaemia, multiple myeloma, and plasma cell leukaemia. In acute myeloid leukaemia blasts show no activity, except in megakaryoblastic leukaemia, in which only a few cells showed the reaction. The enzyme actuity is variable in Common ALL and when present, it represents a small percentage of cells. DAP IV cytochemistry may be useful in the follow up of patients with Sézary syndrome and hairy cell leukaemia.

We thank Mr M Barber for technical assistance, $\mathrm{Mr}$ R Flemans for photographic advice, and Mrs E Cousson for typing the manuscript. MRK was supported by a scholarship from Asyut University, Asyut, Egypt. FGJH is the Leukaemia Research Fund Professor of Haematological Medicine. PCB was supported by a grant from the Leukaemia Research Fund.
References

${ }^{1}$ Lojda Z. Studies on glycyl-proline naphthylamidase. I. Lymphocytes. Histochemistry 1977;54:299-309.

${ }^{2}$ Lojda Z. Proteinases in pathology. Usefulness of histochemical methods. J Histochem Cytochem 1981;29:481-93.

${ }^{3}$ Lojda Z, Heřmanský F, Benesová E, Salková J, Lodrová V. O Dipeptidylaminopeptidase IV in lymphocytes of peripheral $\overline{\bar{\omega}}$ blood of man and the importance of its evidence in malignant lymphoma. Sbornik Lékařský 1979;81(7):200-7.

${ }^{4}$ Feller AC, Parwaresch MR. Specificity and polymorphism of diaminopeptidase IV in normal and neoplastic T lymphocytes. J Cancer Res Clin Oncol 1981;101:59-63.

${ }^{5}$ Feller AC. Cytochemical reactivity of $\mathrm{T}$ lymphocytes in human lymphatic tissue for dipeptidylaminopeptidase IV. Histochem $J \vec{\omega}$ 1982;14:889-95.

${ }^{6}$ Feller AC, Heijnen CJ, Ballieux RE, Parwaresch MR. Enzyme histochemical staining of T lymphocytes for glycyl-proline-4methoxy-beta-naphthylamide-peptidase (DAP) IV. Br J Haematol 1982;51:227-34.

${ }^{7}$ Wirthmüller R, Dennig D, Oertel J, Gerhartz H. Dipeptidylaminopeptidase IV (DAP IV) activity in normal and malignant $T$ cell subsets as defined by monoclonal antibodies. Scand J Haematol 1983;31:197-205.

${ }^{8}$ Feller AC, Parwaresch MR, Lennert K. Cytochemical distribution of dipeptidylaminopeptidase IV (DAP IV; EC 3.4.14.5) in Tlymphoblastic lymphoma/leukaemia characterised with monoclonal antibodies. Leuk Res 1984;8:397-406.

${ }^{9}$ Crockard AD, MacFarlane E, Andrews C, Bridges JM, Catovsky D. Dipeptidylaminopeptidase IV activity in normal and leu- $\vec{\theta}$ kaemic T-cell subpopulations. Am J Clin Pathol 1984;82:294-9. @

${ }^{10}$ Invernizzi R, Bertolino G, Girino M, Perseghin P, Michienzi M, Nano R. Cytochemistry of dipeptidyl-amino-peptidase IV (DAP IV) and II (DAP II) in normal and neoplastic lymphoid cells. Blut 1985;50:277-85.

${ }^{11} \mathrm{Kaplan}$ ME, Clark C. An improved rosetting assay for detection of human T-lymphocytes. J Immunol Methods 1974;5:131-5.

${ }^{12}$ Lojda Z, Gossrau R, Schiebler TH. Enzyme histochemistry. Laboratory manual. Berlin: Springer Verlag, 1979.

${ }^{13}$ Hayhoe FGJ. Leucocyte cytochemistry. Broadsheet 96. London: Association of Clinical Pathologists, British Medical Association, 1981.

${ }^{14}$ McDonald JK, Schwabe C. Intracellular exopeptidases. In: Barrett AJ, ed. Proteinases in mammalian cells and tissues. 2nd ed. Amsterdam: North-Holland, 1977.

${ }^{15}$ Goldschneider I. Heterogeneity of bone marrow "lymphocytes" Clin Haematol 1982;11(3):491-508.

${ }^{16}$ Gossrau R, Lojda Z. Study on dipeptidylpeptidase II (DAP II) Histochemistry 1980;70:53-76.

${ }^{17}$ Chilosi M, Pizzolo G, Menestrina F, Iannucci AM, Bonetti F, Fiore-Donati L. Dipeptidyl (amino) peptidase IV (DAP IV) histochemistry on normal and pathologic lymphoid tissues. Am $J$ Clin Pathol 1982;77:714-9.

${ }^{18} \mathrm{Khalaf}$ MR, Aqel NM, Hayhoe FGJ. Histochemistry of dipeptidylaminopeptidase (DAP) II and IV in reactive lymphoid tissues and malignant lymphoma. J Clin Pathol 1986;39:891-6. O

Requests for reprints to: Professor FGJ Hayhoe, Department of Haematological Medicine, Hills Road, $\underset{-}{\sigma}$ Cambridge CB2 2QL, England. 